\title{
Coleta e análise de dados em estudo de reconhecimento da realidade profissional e do ensino de design de serviços em cursos de graduação nos estados de São Paulo e do Rio de Janeiro
}

\author{
Camilla Fernanda Annarumma Durão, Cristiane Aun Bertoldi
}

ensino de design; design de serviços; competências; métodos; prática do design

Este trabalho tem por objetivo compartilhar os métodos utilizados e oportunidades e desafios encontrados durante as etapas de coleta e análise de dados da pesquisa sobre o atual cenário profissional

Curso

Mestrado

\section{Linha de Pesquisa}

Teoria e História do Design

\section{Camilla Fernanda Annarumma Durão}

Bacharel e mestranda em Design pela USP, com atuação e pesquisa focadas nos temas do design de serviços e design para inovação social. Atualmente é gerente de inovação e líder de projetos na consultoria MJV e é professora no curso de Gestão Estratégica da Inovação na pós-graduação do Senac.

e-mail: annarumma@usp.br Lattes: http://lattes.cnpq. br/1565979307777009

Orcid: https://orcid.org/0000-

0001-9580-4981

\section{Cristiane Aun Bertoldi}

Professora doutora na Universidade de São Paulo na graduação e pós-graduação em Design; colíder do grupo de pesquisa Design em Ação. Recentes pesquisas envolvem criatividade, processos criativos e métodos de projeto; materiais para o design, ensino de design e design para saúde.

e-mail: craun@usp.br

Lattes: http://lattes.cnpq.

br/1791567263251867

Orcid: https://orcid.org/0000-

0002-3792-5221 e acadêmico em design de serviços. Apesar deste campo ter sua relevância reconhecida em uma sociedade pós-industrial, o design, como um todo, permanece disseminado com orientação para o setor produtivo, com um ensino especialmente focado nas características e necessidades deste setor (MORITZ, 2005; COUTO, 2008; MAGER, 2009). Com o intuito de analisar experiências e expectativas entre academia e mercado, está sendo conduzido um estudo qualitativo constituído de revisão bibliográfica, mapeamento de cursos de graduação em design que oferecem disciplinas de design de serviços e estudo de reconhecimento desses casos, além da análise da experiência em empresas, selecionadas de acordo com os setores que mais investem em design de serviços. Serão analisadas as matrizes curriculares de cursos que receberam avaliação 4 ou 5 no Guia do Estudante e dentre os cursos não avaliados pelo Guia, serão considerados aqueles com nota 4 ou 5 nos principais indicadores do MEC (CC, CPC e Enade). Serão aplicados questionários e entrevistas com coordenadores, professores, alunos e egressos. A pesquisa contempla cursos e empresas nos estados do Rio de Janeiro e de São Paulo, devido a sua representatividade no setor de serviços no PIB (IBGE, 2020). Ao fim da pesquisa pretende-se apresentar análises comparativas entre os âmbitos acadêmico e profissional, considerando a triangulação entre instituições de ensino, alunos e empresas. Também serão feitas recomendações de conhecimentos e habilidades em design que podem ser considerados na estruturação das grades curriculares e programas de disciplinas de design de serviço. 


\title{
Data collection and analysis in recognition study on the current professional and academic scenario in service design in undergraduate courses in São Paulo and Rio de Janeiro states
}

\author{
Camilla Fernanda Annarumma Durão, Cristiane Aun Bertoldi
}

design education; service design; skills; methods; design practice

This work aims to discuss the applied methods, opportunities and challenges faced along the stages of data collection and analysis of an ongoing research on the current professional and academic scenarios of service design. Despite the recognized importance of this field in a post-industrial society, the design as a whole still remains disseminated as industry oriented, with teaching especially focused on the features and needs of this sector (MORITZ, 2005; COUTO, 2008; MAGER, 2009). A qualitative study is being conducted in order to analyze experiences and expectations between academic and marketing scopes, and it consists of bibliographic review, mapping of undergraduate Design courses that offer service design

Course

Master

\section{Line of Research}

Design Theory and History

\section{Camilla Fernanda Annarumma \\ Durão}

Undergraduate and Msc. student in Design at University of São Paulo with professional experience and scientific research focused on service design and design for social innovation. Currently is Innovation Manager at MJV Technology $\&$ Innovation and professor at Senac's post-graduation program. e-mail: annarumma@usp.br Lattes: http://lattes.cnpq. br/1565979307777009

Orcid: https://orcid.org/00000001-9580-4981

\section{Cristiane Aun Bertoldi}

PhD, Professor of the undergraduate and postgraduate Design Courses at University of São Paulo, co-chair of the research group Design in Action. Recent researches involve creativity, creative process and design methods, materials for design, design teaching and design for health.

e-mail: craun@usp.br

Lattes: http://lattes.cnpq. br/1791567263251867

Orcid: https://orcid.org/00000002-3792-5221 disciplines and a recognition study of these cases, in addition to the analysis of professional experience in selected companies. From the sectors that most invest in service design. An analysis will be made from the curriculum of courses that received a rating of 4 or 5 in the Student Guide and among the courses not evaluated by the Guide, will be considered those with a score of 4 or 5 in the main MEC indicators (CC, CPC and Enade). Then surveys and interviews will be applied with coordinators, teachers, students and alumni. The research comprises courses and companies in the states of Rio de Janeiro and São Paulo, due to their representativeness in the services sector in the GDP (IBGE, 2020). The research endeavors to achieve the comparative analysis between academic and professional spheres considering the triangulation between educational institutions, students and companies. Recommendations of knowledge and skills that could be taken into account during the development of the curriculum and service design programs will also be made.

\section{Referências | References}

COUTO, R. M. 2008. Escritos Sobre Ensino de Design no Brasil. Rio de Janeiro: Rio Books.

IBGE. 2020. Pesquisa Anual de Serviços 2018. 〈https://biblioteca.ibge.gov.br/ visualizacao/periodicos/150/pas_2018_v20_informativo.pdf〉, 12/10/2020.

MAGER, B. 2009. Service Design as an Emerging Field. Designing Services with Innovative Methods. Helsinki: Helsinki Univesity of Art and Design.

MORITZ, S. 2005. Service Design: Practical Access To An Evolving Field. Köln: Köln International School of Design. 